\title{
THE EFFECT OF A COLLABORATIVE EXPERIENTIAL LEARNING MODEL USING THE DIGITAL MARKETPLACE TO ENHANCE THE DIGITAL ENTREPRENEURSHIP OF UNDERGRADUATE STUDENTS
}

\author{
Trongtorsak $\mathrm{S}^{1^{*}}$, Saraubon $\mathrm{K}^{2}$ and Nilsook $\mathrm{P}^{1}$ \\ ${ }^{I}$ Division of Information and Communication Technology for Education, Faculty of \\ Technical Education, King Mongkut's University of Technology North Bangkok, Bangkok, \\ Thailand \\ ${ }^{2}$ Department of Computer and Information Science, Faculty of Applied Science, King \\ Mongkut's University of Technology North Bangkok, Bangkok, Thailand
}

\begin{abstract}
Internet technology has transformed traditional commerce, resulting in entrepreneurship becoming digital entrepreneurship. Consequently, a learning process that encourages learners to enhance their digital entrepreneurship is essential for the 21st Century. This research aims to study academic achievement by utilizing the collaborative experiential learning model using the digital marketplace and comparing academic achievement. The research approach is divided into 2 phases: a study of academic achievement utilizing the collaborative experiential learning model using the digital marketplace and compare academic achievement with more traditional learning approaches. The sample groups consisted of three groups. The participants were selected using random cluster sampling. Data collection was done using pretest-posttest and the standard deviation (S.D.), t-test, and one-way analysis of covariance (ANCOVA) of the data were used for statistical analysis. The research results found that: the academic performance of the learner group utilizing the collaborative experiential learning model using the digital marketplace was higher than that of the learner groups using the collaborative experiential learning process and the traditional instruction method. In addition, each of the groups considered exhibit a different academic achievement. The fact that there is higher academic achievement utilizing the collaborative experiential learning model using the digital marketplace shows that instructors can use this model for instruction purposes.
\end{abstract}

Keywords: collaborative experiential leaning, digital marketplace, digital entrepreneurship

\section{Introduction}

A suitable learning in the $21^{\text {st }}$ Century is Collaborative Experiential Learning (Trongtorsak et al., 2021) in that it is one which creates knowledge through exchanging experiences. It emphasizes the creation of an experience that facilitates self-learning by gaining experience before learning, taking what has been observed and considering it in small groups in order to discuss the results (Laal et al., 2013; Kolb, 2014; Kang and Chen, 2016; Shiralkar, 2016; Pangestu et al., 2019; Neto and Fernandes, 2019). 
The rapid growth of information and communication technology (ICT) is increasingly affecting all areas of life. This means that it is essential for education to undergo widespread changes (Shawky et al., 2014) and to incorporate new technological phenomena that influence peoples' final decisionmaking concerning their business, marketing, and career activities in different organizations (Kuandee et al., 2019). Additionally, digital technology changes how people do business and create start-ups (Vorbach et al., 2019). What is clearly different is the emergence of the Digital Marketplace. It has transformed many business processes in almost every sector (Anshari et al., 2019). It is a channel for transactions through platforms on the internet. There is now a massive collection of merchandise and shops which act as a medium for buying and selling products (Cruz-Cunha et al., 2013; Fajar and Sandhyaduhita, 2016). Digital technology has resulted in digital entrepreneurs' creation. This is a phenomenon that occurs through the adoption of technology assets such as the internet and the use of information and communication technology.

In the past few decades, digital technology has been widely used in global society. Moreover, it is now applied at all levels of education. These digital technologies are creating attractive innovation opportunities for entrepreneurs (Vorbach et al., 2019). A Digital Entrepreneur is an entrepreneur who can use digital media and technology to develop management and business strategy, and who can build competitiveness by applying the knowledge of technology to improve the traditional business processes, according to Welsum (2016), Sussan and Acs (2017) and Guthrie (2014).

\section{Research Objectives}

The objectives of this research are:

1. To study the academic achievement based on collaborative experiential learning model using the digital marketplace.

2. To compare the academic achievement based on the collaborative experiential learning model using the digital marketplace with more traditional learning approaches.

\section{Research Methodology}

The research process was divided into two distinct stages as follows:

Stage I - A study of academic achievement based on a collaborative experiential learning model using the digital marketplace.

Stage II - A comparison of academic achievement based on the collaborative experiential learning model using the digital marketplace with more traditional learning approaches.

\section{Research Design}

This study utilized an experimental research design involving matching the pretest-posttest results. The three groups used consisted of one control group and two experimental groups; were both experimental groups given special treatment. Details are as shown in Table 1. 
Table 1. Matching Pretest-Posttest

\begin{tabular}{llll}
\hline Group & Pre-test & Treatment & Post-test \\
\hline Group A (Experiment) & $\mathrm{O}_{1}$ & $\mathrm{X}_{1}$ & $\mathrm{O}_{2}$ \\
\hline Group B (Experiment) & $\mathrm{O}_{1}$ & $\mathrm{X}_{2}$ & $\mathrm{O}_{2}$ \\
\hline Group C (Control) & $\mathrm{O}_{1}$ & - & $\mathrm{O}_{2}$ \\
\hline
\end{tabular}

Before conducting this experiment, three sample groups were chosen - Group A, Group B (experiment group), and Group C (control group), were given the same pretest questions. The purpose of pretest was to observe the students' initial conditions before providing treatment in the experimental group and the conventional treatment given to the control group. Group A's treatment is a collaborative experiential learning model using the digital marketplace, group B was a collaborative experiential learning process while group $\mathrm{C}$ (the control group) was taught using conventional media. After the treatment was undertaken, all the three groups were provided with the same posttest questions.

\section{Participants}

This study participants were undergraduate students in the second semester of the academic year 2019 of Chandrakasem Rajabhat University, Thailand. The participants were divided into three groups. The allocation to groups was based on Cluster Random Sampling.

3. Research Instrument

- The collaborative experiential learning process for enhancing digital entrepreneurship

- The collaborative experiential learning model using the digital marketplace to enhance digital entrepreneurship

- Course handout

- The Digital marketplace

- Digital marketplace manual

- Multiple-choice Pretest Posttest questions (40 items) each consisting of four options.

4. Data Analysis

The statistics used for data analysis were mean, standard deviation, t-test, and one-way analysis of covariance.

\section{Research Hypothesis}

This research presented the research hypothesis as follows.

Student groups learning by a collaborative experiential learning model using the digital marketplace, a collaborative experiential learning process and learning through traditional instruction methods had different academic achievements.

\section{Research Results}

Academic achievement based on a collaborative experiential learning model using the digital marketplace 
The participants were pretested and posttested. The changes made by the learners participating in the study are described in this section. Details are provided in Table 2

Table 2. The result of participants' pretest and posttest scores

\begin{tabular}{lllll}
\hline & & $\mathrm{N}$ & Mean & Std. Deviation \\
\hline \multirow{2}{*}{ Group A (Experiment) } & Pretest & 30 & 14.93 & 5.54 \\
& Posttest & 30 & 32.27 & 4.72 \\
\hline \multirow{2}{*}{ Group B (Experiment) } & Pretest & 30 & 13.13 & 5.30 \\
& Posttest & 30 & 24.33 & 4.67 \\
\hline \multirow{2}{*}{ Group C (Control) } & Pretest & 30 & 11.20 & 4.60 \\
& Posttest & 30 & 21.07 & 4.92 \\
\hline
\end{tabular}

From Table 2, the posttest scores show that the mean of the experimental group (Group A) was 32.27, and the standard deviation (S.D.) was 4.72, while in terms of the pretest scores, the mean was 14.93 , and the standard deviation (S.D.) was 5.54. The results with regard to the posttest scores show that the mean of the experimental group (Group B) was 24.33, and the standard deviation (S.D.) was 4.67. Finally, with regard to the pretest scores, the mean was 13.13 and the standard deviation (S.D.) was 5.30, while for the posttest scores the results show that the mean of the control group (Group C) was 21.07, and the standard deviation (S.D.) was 4.92 while for the pretest scores, the mean was 11.20 and the standard deviation (S.D.) was 4.60 .

\section{Academic achievement comparison result}

Covariance analysis (ANCOVA) was used to compare the three groups' achievement scores. The pretest score was used as a covariate. Details are provided in Table 3.

Table 3. Results of analysis of covariance for the groups' achievement scores

\begin{tabular}{lcclll}
\hline Source & $\begin{array}{l}\text { Type III } \\
\text { Sum of Squares }\end{array}$ & df & Mean Square & F & Sig \\
\hline Group*Pretest & 1193.758 & 1 & 1193.758 & 130.508 & $.000^{* *}$ \\
Group & 1113.252 & 2 & 556.626 & 60.853 & $.000^{* *}$ \\
Error & 786.642 & 86 & 9.147 & & \\
Total & 3970.889 & 89 & & & \\
\hline
\end{tabular}

$* * \mathrm{p}<.01(\mathrm{R}$ Squared $=.804$, Adjusted R Squared $=.797)$

In terms of the results in Table 3 , the covariance analysis results comparing academic achievement found that $\mathrm{F}(2,86)=60.853, \mathrm{p}=.000<.01$. This shows that all groups had an academic achievement mean score that was statistically different at a significance level of .01 . The researcher then made a pairwise comparison using the LSD method. The values are as shown in Table 4. 
Table 4. Result of analysis pairwise comparisons using LSD method

\begin{tabular}{lllll}
\hline (I) Group & (J) Group & $\begin{array}{l}\text { Mean Difference } \\
(\mathrm{I}-\mathrm{J})\end{array}$ & Std.Error & Sig. \\
\hline E1 & E2 & $7.933^{*}$ & 1.232 & $.000^{* *}$ \\
\hline & $\mathrm{C}$ & $11.200^{*}$ & 1.232 & $.000^{* *}$ \\
\hline E2 & E1 & $-7.933^{*}$ & 1.232 & $.000^{* *}$ \\
\hline & $\mathrm{C}$ & $3.266^{*}$ & 1.232 & $.010^{*}$ \\
\hline $\mathrm{C}$ & $\mathrm{E} 1$ & $-1.200^{*}$ & 1.232 & $.000^{* *}$ \\
\hline & $\mathrm{E} 2$ & $-3.266^{*}$ & 1.232 & $.010^{*}$ \\
\hline$* * \mathrm{p}<011^{*}<05$ & & & &
\end{tabular}

$* * \mathrm{p}<.01 * \mathrm{p}<.05$

The result of pairwise comparisons of the three different pairs is as follows:

- The academic performance of the participants of Group A and Group B are different.

- The academic performance of the participants of Group A and Group C are different.

- The academic performance of the participants of Group B and Group C are different.

\section{Discussion and conclusion}

Based on the results, the academic performance increased in all three groups. The mean scores of the participants in group A, group B, and group C at the pretest stage were 14.93, 13.13, and 11.20, respectively, which changed to $32.27,24.33$, and 21.07 respectively in the posttest. The results of the ANCOVA analysis, showed the significance value was $0.0000(\mathrm{p}<.001)$.

This mean that there is a difference in academic performance between the learners who learned as a result of the collaborative experiential learning model using the digital marketplace to enhance digital entrepreneurship, those who learned as a result of the collaborative experiential learning process for enhancing digital entrepreneurship, and those who learned through traditional instruction methods. The participants of group A had an academic performance mean score higher than that of the participants in group B. The participants in group A had an academic performance mean score higher than that of the participants of group C, while the participants of group B had an academic performance mean score higher than that of the participants of group $\mathrm{C}$.

\section{Acknowledgements}

I would like to thank King Mongkut's University of Technology North Bangkok, Thailand (KMUTNB) for it support.

\section{References}

Anshari, M., Almunawar, M. N., Masri, M., \& Hamdan, M. (2019). Digital marketplace and FinTech to support agriculture sustainability. Energy Procedia, 156, 234-238.

Cooper, L. and Burford, S. (2010). Collaborative Learning: Using Group Work Concepts for Online Teaching. In Martin, J., \& Hawkins, L. (Ed.), Information Communication Technologies for Human Services Education and Delivery: Concepts and Cases (pp. 37-52). IGI Global. https://doi.org/ 10.4018/978-1-60566-735-5.ch003 
Cruz-Cunha, M. M., Varajao, J., Miranda, I., Lopes, N., \& Simoes, R. (2013). An e-marketplace of healthcare and social care services: the perceived interest. The Learning Organization, 20(6), 406-418. https://doi.org/10.1108/TLO-10-2013-0055

Fajar, N. K., \& Sandhyaduhita, P. I. (2016, October). Supporting factors of sellers' reputation in e-marketplace: A case of Indonesia. In 2016 International Conference on Advanced Computer Science and Information Systems (ICACSIS) (pp. 215-220). IEEE.

Guthrie, C. (2014). The digital factory: A hands-on learning project in digital entrepreneurship. Journal of Entrepreneurship Education, 17(1), 115.

Kang, Y. C., \& Chen, J. Y. (2016). Applying Kano Model to Evaluate the Quality for Mobile Experiential Learning Model. IN 2016 International Conference on Applied System Innovation (ICASI) (pp.1-3). IEEE. https://doi.org/10.1109/ICASI.2016.7539882

Kolb, D. A. (2014). Experiential Learning: Experience as the source of learning and development. FT press.

Korajman, I. (2019). Digital Entrepreneurship Education: The Role of MOOCs. International Journal of Engineering Pedagogy, 9(3).

Kuandee, W., Nilsook, P., \& Wannapiroon, P. (2019). Asset Supply Chain Management Systembased IoT Technology for Higher Education Institutions. International Journal of Online and Biomedical Engineering, 15(3), 4-20. https://doi.org/10.3991/ijoe.v15i03.8533

Laal, M., Geranpaye, L., \& Daemi, M. (2013). Individual accountability in collaborative learning. Procedia - Social and Behavioral Sciences, 93, 286-289. https://doi.org/10.1016/j.sbspro.2013.09.191

Neto, A. J. M., \& Fernandes, M. A. (2019). Chatbot and Conversational Analysis to Promote Collaborative Learning in Distance Education. In 2019 IEEE 19th International Conference on Advanced Learning Technologies (ICALT) (pp. 324-326). IEEE.

Pangestu, H., Karsen, M., \& Chandra, Y. U. (2019). Evaluation of Collaborative Learning Tools Implementation to Improve Learning Quality in Higher Education. In 2019 International Conference on Information Management and Technology (ICIMTech) (pp. 477-481). IEEE.

Shawky, D., Badawi, A., Said, T., \& Hozayin, R. (2014). Affordances of computer-supported collaborative learning platforms: a systematic review. In 2014 International Conference on Interactive Collaborative Learning (ICL) (pp. 633-651). IEEE.

Shiralkar, S. W. (2016). IT Through Experiential Learning: Learn, deploy and adopt IT through gamification. https://doi.org/10.1007/978-1-4842-2421-2

Sussan, F., \& Acs, Z. J. (2017). The digital entrepreneurial ecosystem. Small Business Economics, 49(1), 55-73.

Trongtorsak, S., Saraubon, K., \& Nilsook, P. (2021). Collaborative Experiential Learning Process for Enhancing Digital Entrepreneurship. Higher Education Studies, 11(1). 137-147.

van Welsum, D. (2016). Enabling digital entrepreneurs. World Development Report. Retrieved from http://documents.worldbank.org/curated/en/2016/02/25851780/world-development-report-2016-

digital-dividends-enabling-digital-entrepreneurs

Vorbach, S., Poandl, E. M., \& Korajman, I. (2019). Digital Entrepreneurship Education: The Role of MOOCs. International Journal of Engineering Pedagogy, 9(3).

Yilmaz-Soylu, M., \& Akkoyunlu, B. (2009). The Effect of Learning Styles on Achievement in Different Learning Environments. Turkish Online Journal of Educational Technology-TOJET, 8(4), 43-50. 